\title{
Assessment of the prevalence of vertical hepatitis B transmission in two consecutive generations
}

\author{
Larissa Akeme Nakano ${ }^{1 *} \odot$, Jéssica Toshie Katayose ${ }^{1}$, Rodrigo Martins Abreu², luis Cláudio Alfaia Mendes², \\ Maria Cleusa Martins ${ }^{1}$, Vanusa Barbosa Pinto ${ }^{1}$, Flair José Carrilho², Suzane Kioko Ono ${ }^{2}$ \\ ${ }^{1}$ Division of Pharmacy, Hospital das Clínicas da Faculdade de Medicina da Universidade de São Paulo (HC-FMUSP), São Paulo, SP, Brazil \\ ${ }^{2}$ Division/Department of Gastroenterology and Hepatology, HC-FMUSP, São Paulo, SP, Brazil
}

Study conducted at Hospital das Clínicas da Faculdade de Medicina da Universidade de São Paulo (HC-FMUSP), São Paulo, SP, Brazil

Article received: $6 / 5 / 2017$ Accepted for publication: 7/16/2017

*Correspondence: Instituto Central, Hospital das Clínicas Address: Av. Dr. Enéas de Carvalho Aguiar, $255,9^{\circ}$ andar, sala 9.159 São Paulo, SP - Brasil Postal code: 05403-000 larissa.nakano@hc.fm.usp.br

\section{SUMmARY}

Introduction: Hepatitis B is an important public health problem in the world and one of the forms of contagion would be through vertical transmission. Precose diagnosis allows the adoption of prophylaxis measures, which results in prevention in more than $90 \%$ of cases.

Objective: To describe the prevalences of vertical transmission and compare two generations (mother/patient and patient/child).

Method: This was a cross-sectional study, which included 101 patients. The interviews were performed through the application of the instrument of data collection and information of the physical file before the medical consultation. Results: The mean \pm SD of age was $50.9 \pm 13$.1 years, the male gender predominated, with $56.4 \%$ of the patients, and the predominance was white, with $43.6 \%$. Vertical transmission between mother and patient occurred in $17.8 \%$ and between patient and child, in $7.9 \%$. In all of the eight cases of vertical transmission, the diagnosis was after the birth of children infected with HBV, and in $3 / 8(37.5 \%)$, there was more than one case of infection by this mechanism per patient, totaling 13 children with the disease.

Conclusion: There was a reduction in vertical transmission, showing that preventive measures were effective.

Keywords: Hepatitis B. Infectious Disease Transmission, Vertical. Antiviral Agents.

\section{INTRODUCTION}

Chronic infection caused by hepatitis B virus (HBV) is a major public health problem. ${ }^{1-3}$ According to the World Health Organization (WHO), approximately 2 billion people have been exposed to the virus. Of these, 240 million are estimated to have the chronic form of the disease. Hepatitis B accounts for about 786,000 deaths per year worldwide. ${ }^{2,4,5}$

Hepatitis B is the most common form of chronic hepatitis and is caused by a DNA virus that belongs to the Hepadnaviridae family. There exist ten genotypes of $\mathrm{HBV}$, which are named from A to J. They differ from one another in their nucleotide sequence in the genome, varying as to geographic distribution. The infection can cause acute or chronic hepatitis, both forms being usually oligosymptomatic. ${ }^{5}$
Chronic hepatitis B can be divided into four phases. First phase: immune tolerance; second phase: immune clearance; third phase: inactive carrier; and fourth phase: reactivation. The main goal of treatment is to reduce the risk of progression of liver disease and its primary outcomes, specifically cirrhosis, hepatocellular carcinoma (HCC) and, consequently, death. Pharmacological options for the treatment of hepatitis B are: interferon-alpha, lamivudine, peg-interferon-alpha $2 \mathrm{a}$ and $2 \mathrm{~b}$, adefovir, entecavir, telbivudine, and tenofovir. ${ }^{1,5,6}$

Vertical hepatitis B transmission may occur during acute or chronic maternal infection through exposure of fetal mucous membranes to HBV-infected blood or maternal bodily fluids, which may occur before birth, transplacentally (intrauterinely) or at the time of childbirth (perinatally). Occasionally, the child's infection occurs in the 
postnatal period through contact with infected adults. When acute $\mathrm{HBV}$ infection occurs during the first trimester of pregnancy, the risk of transmission to the newborn (NB) is less than $10 \%$. However, when the infection occurs in the second or third trimesters, transmission may occur in more than $60 \%$ of cases. Therefore, it is recommended that all pregnant women perform a rapid test for $\mathrm{HBV}$ at their first visit, in the first trimester, or when they begin prenatal care. The diagnosis makes it possible to adopt prophylaxis measures, therefore ensuring that the vaccine and human antihepatitis B immunoglobulin will be administered during the first 12 hours of life of the newborn. This prevents perinatal transmission in more than $90 \%$ of cases. ${ }^{3,5-7}$

Care to pregnant women with hepatitis B should be given so as to prevent the vertical transmission of infection to newborns and treat the disease in mothers. Family planning should always be discussed with women of childbearing potential before starting any therapeutic procedure, especially antiviral therapy for hepatitis B. $3,4,7,8$

\section{Method}

\section{Study design}

This is a cross-sectional study conducted from June 2016 to December 2016 with patients having chronic hepatitis $B$ infection and who were being followed up at the Clinical Hepatology Outpatient Clinic of Instituto Central, Hospital das Clínicas, Faculdade de Medicina, Universidade de São Paulo (ICHC-FMUSP), a tertiary-level university hospital that operates seamlessly with Brazil's Unified Health System (Sistema Único de Saúde, SUS, in the portuguese acronym). It is internationally well-known for providing medical care and treatment for high-complexity patients.

By using the Hospital Information and Management System (Sistema de Informação e Gestão Hospitalar, SIGH, in the Portuguese acronym), it was possible to generate a Report of Scheduled Visits (Relatório de Consultas Agendadas) and thus obtain patient listings. The interviews were conducted by administering a data collection instrument and supplemented with the medical record information prior to the visit with a medical consultation with the purpose of assessing the prevalence of vertical hepatitis $\mathrm{B}$ transmission in two generations (mother/patient and patient/offspring).

\section{Inclusion and exclusion criteria}

Inclusion criteria: patients from the clinical hepatology outpatient clinic at HC-FMUSP, of both genders, aged $\geq 18$ years, diagnosed with chronic hepatitis B infection (tested positive for HBsAg for more than six months), with children and who agreed to sign a free informed consent form. Exclusion criteria: co-infection with the hepatitis $\mathrm{C}$ virus and HIV.

\section{Ethical aspects}

Our project was submitted for evaluation by the Research Ethics Committee of HC-FMUSP (Cappesq) and over Plataforma Brasil (a national and unified database of research records involving human subjects) alongside with its CAEE (a submission protocol number): 56746916.4.0000.0068, opinion No. 1.592 .921 on June 16, 2016. All patients meeting the inclusion criteria and none of the exclusion criteria were asked to read, discuss and sign a free informed consent form prior to the interviews.

\section{Statistical analysis}

The data collected were stored in an Excel $®$ database. The results from the descriptive analysis were expressed as mean, median, standard deviation, maximum and minimum values, and frequency distribution. They were then depicted in graphs and tables.

\section{Results}

We selected 193 patients, of whom 92 were excluded: 39 who did not show up in the outpatient clinic, nine because they did not accept to participate in the study, six who tested negative for HBsAg, 36 for not having had children, and two because they met the exclusion criteria. Once the selection criteria were applied, a total of 101 patients comprised the study sample.

With respect to the distribution by gender, age, ethnicity and number of school years completed, the data obtained are shown in Table 1 . The mean \pm SD age was $50.9 \pm 13.1$ years, with a larger number of male participants, i.e. $57 / 101(56.4 \%)$ of all selected patients, and also a larger number of caucasians, i.e. 44/101 (43.6\%). The distribution according to number of school years completed showed similar values of patients who completed primary education 37/101 (36.6\%) and high school 40/101 (39.6\%).

Regarding the pharmacological regimen currently used, the use of tenofovir $300 \mathrm{mg}$ as monotherapy was predominant, with 20/101 (19.8\%) patients. Still, the non-use of antivirals was found in 46/101 (45.5\%) patients, a larger number when compared to monotherapy, 40/101 (39.6\%) or combination therapy, 15/101 (14.9\%).

With regard to the likely form of transmission, vertical transmission was found in 18/101 (17.8\%) patients. Most patients, 50/101 (49.5\%), do not know how they got infected. Yet, 4/101 (3.9\%) patients reported causes that are known not to be forms of infection, such as "lack of hygiene when living in the countryside," "working with charcoal," subway/train, or "bathing in the river." 
TABLE 1 Distribution of traits according to gender, age, ethnicity and number of school years completed. June/2016 to

December/2016 $(n=101)$.

\begin{tabular}{|c|c|c|c|c|}
\hline Variable & N (\%) & Mean (minimum and maximum) & Standard deviation & Median \\
\hline \multicolumn{5}{|l|}{ Gender } \\
\hline Female & $44 / 101(43.6)$ & & & \\
\hline Male & $57 / 101(56.4)$ & & & \\
\hline Age & & $50.9(25-82)$ & 13.1 & 52 \\
\hline $20-30$ years & $5 / 101(4.9)$ & & & \\
\hline $31-40$ years & 13/101 (12.9) & & & \\
\hline $41-50$ years & 24/101 (23.8) & & & \\
\hline $51-60$ years & $30 / 101(29.7)$ & & & \\
\hline $61-70$ years & $23 / 101(22.8)$ & & & \\
\hline $71-80$ years & $5 / 101(4.9)$ & & & \\
\hline$>81$ years & $1 / 101(1.0)$ & & & \\
\hline \multicolumn{5}{|l|}{ Race } \\
\hline White & $44 / 101(43.6)$ & & & \\
\hline Black & 12/101 (11.9) & & & \\
\hline Yellow & 14/101 (13.8) & & & \\
\hline Brown/Mixed & $30 / 101(29.7)$ & & & \\
\hline Indigenous & $1 / 101(1.0)$ & & & \\
\hline \multicolumn{5}{|l|}{ Education } \\
\hline Illiterate & $1 / 101(1.0)$ & & & \\
\hline Primary and Middle school & $37 / 101(36.6)$ & & & \\
\hline High school & 40/101 (39.6) & & & \\
\hline Higher studies & $23 / 101(22.8)$ & & & \\
\hline
\end{tabular}

Vertical transmission can occur at two moments: mother/patient and patient/offspring. The vertical transmission rates we found in our study were 18/101 (17.8\%) and 8/101 (7.9\%), respectively (Figure 1).

Regarding the use of prophylaxis tools in the offspring, we found that immunoprophylaxis after childbirth represented 10/101 (9.9\%); of these, there was no transmission of hepatitis B, and 68/101 (67.3\%) were vaccinated, with only $3 / 68(4.4 \%)$ patients having hepatitis B. With regard to the unvaccinated offspring, 33/101 (32.7\%), 6/33 (18.2\%) had hepatitis B.

When analyzing the vertical transmission rate among the patients interviewed, $8 / 101$ (7.9\%), we found that $7 / 8$ (87.5\%) are females and the only male has a wife with HBV. Offspring with HBV were $34 \pm 6.2$ (mean \pm SD) years old. None of them received immunoprophylaxis, whereas 4/13 (30.8\%) were vaccinated.

We found that all eight cases of vertical transmission were diagnosed after the birth of the HBV-infected offspring. In $3 / 8$ (37.5\%), there was more than one case of infection by this mechanism per patient, therefore totaling 13 children with the disease, as shown in Table 2.

\section{Discussion}

In the period from 1999 to 2015, 196,701 cases of hepatitis B in Brazil, a notifiable disease, were notified through the Notification Information System (Sistema de Informação de Agravos de Notificação, SINAN). Of these, $106,371(54.1 \%)$ correspond to affected males, which is in agreement with the findings of our study, i.e. $56.4 \%$. However, that difference in the number of cases according to gender has been decreasing over the years. The 2015 distribution of cases according to ethnicity/skin color shows that most cases are of Caucasians/white people (50.2\%), which is similar to the value we found, $43.6 \%{ }^{9}$

One way to promote health is by investing in health education actions so that the population has access to information on the disease. This also contributes to the debunking of myths and prejudices. Of the patients interviewed, 4/101 (3.9\%) reported "causes" that are known not to be mechanisms of infection. This is indicative that there are still patients who do not know about their disease, since hepatitis B is known to be a parenterally transmitted; or through the sharing of needles, syringes, manicure and pedicure gear, razor and shave blades; tattooing; 


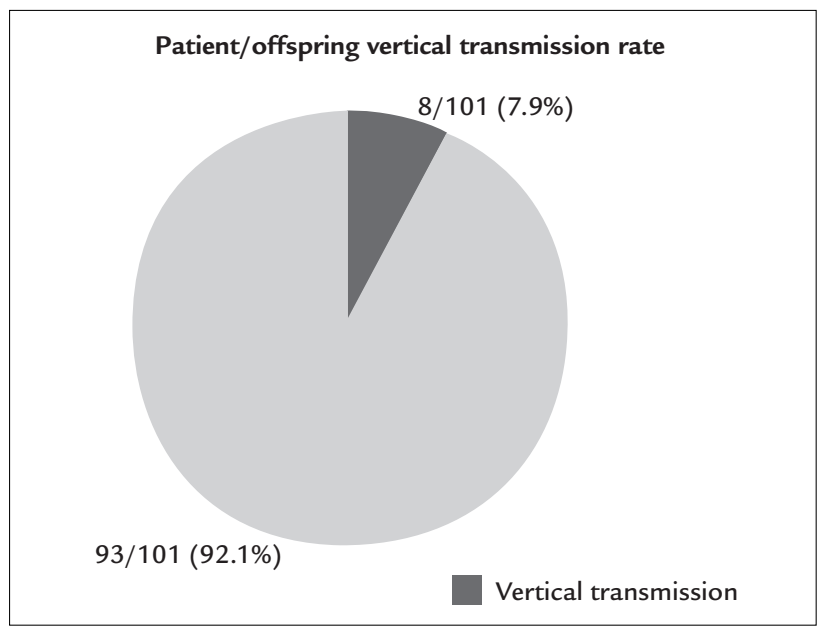

FIGURE 1 Distribution of patients according to patient/offspring vertical transmission. June/2016 to December/2016 ( $n=101)$.

piercing; dental or surgical procedures not meeting biosafety standards; unprotected sex (this being the predominant route); blood transfusion; and vertical transmission (mother/child) - with this being an important route and associated with unfavorable disease progression, with a higher risk of chronification. ${ }^{2,5,10}$

In the transmission between patient/offspring, only 8/101 (7.9\%) were infected through this route, a lower number when compared to mother/patient transmission, $18 / 101$ (17.8\%). Studies show that the infection rate from HBV-carrying mothers to their children amounts to about $90 \%$ of cases when the mother tested positive for HBsAg and antigen "e" (HBeAg-positive) and to $10 \%$ of cases when positive only for HBsAg. ${ }^{8}$

Of the $8 / 101(7.9 \%)$ patients presenting vertical transmission to their children, the last infected child was born in 1995. This shows that, as from that date, the installed measures were effective in preventing this type of transmission, as well as in reducing the vertical transmission rate.

In Brazil, since 1998, the Ministry of Health's National Immunization Program (Programa Nacional de Imunizações, PNI, in the Portuguese acronym) recommends that all children from birth be universally vaccinated against hepatitis B. ${ }^{11}$ The first dose, allied to immunoglobulin within the first 12 hours of birth, results in $95 \%$ efficacy in preventing vertical infection. As from 2001, the age range was extended to 19 years of age. Several studies show that hepatitis $B$ vaccines have good immunogenicity and are effective, providing protection in more than $90 \%$ of healthy young adults and in more than $95 \%$ of infants, children and adolescents. Efficacy decreases gradually after 40 years of age, and
TABLE 2 Description of cases of vertical transmission cases patient/offspring. June/2016 to December/2016 ( $n=101)$

\begin{tabular}{|c|c|c|c|c|c|}
\hline Patient & Gender & $\begin{array}{l}\text { Patient } \\
\text { diagnosis }\end{array}$ & $\begin{array}{l}\text { Number of } \\
\text { offspring }\end{array}$ & $\begin{array}{l}\text { Offspring } \\
\text { with HBV }\end{array}$ & $\begin{array}{l}\text { Year of birth } \\
\text { of the } \\
\text { offspring }\end{array}$ \\
\hline 1 & Female & 2006 & 5 & 1 & 1981 \\
\hline 2 & Female & 2002 & 1 & 1 & 1981 \\
\hline 3 & Female & 1993 & 3 & 3 & $\begin{array}{l}\text { 1982, 1987, } \\
1989\end{array}$ \\
\hline 4 & Female & 1997 & 3 & 1 & 1974 \\
\hline 5 & Male & 1999 & 2 & 1 & 1988 \\
\hline 6 & Female & 2008 & 4 & 3 & $\begin{array}{l}\text { 1980, 1982, } \\
1992\end{array}$ \\
\hline 7 & Female & 2005 & 2 & 2 & 1977,1981 \\
\hline 8 & Female & 1996 & 1 & 1 & 1995 \\
\hline
\end{tabular}

other factors such as obesity, stress, smoking habits and alcohol consumption are also associated with lower vaccine efficacy. ${ }^{11-14}$

Despite the introduction of vaccination and progressive efforts in campaigns, it was found that $9 / 13$ (69.2\%) cases involving vertical transmission had not been vaccinated or did not know whether they had been vaccinated. Among patients who had children, this occurred in $33 / 101(32.7 \%)$ cases - and of these, $6 / 33$ (18.2\%) have $\mathrm{HBV}$. The low vaccine adherence can be explained by the long period necessary for completing the vaccination schedule (three doses: in months 0,1 , and 6). This highlights the need for health education programs geared to raise the population awareness and reinforce the importance of immunization strategies for compliance with the complete $\mathrm{HBV}$ vaccination scheme. ${ }^{3,11}$

With increased access to information and a larger number of campaigns on the disease, the number of new infections is expected to decline. Health promotion begins with prevention measures and educating the population, who need to be informed about everything involving their disease.

\section{Conclusion}

There was a reduction in vertical transmission when comparing the two generations. This shows that even with low immunoprophylaxis rates, the installed measures have been effective in preventing this type of transmission. The importance of health education, raising awareness about vaccination and disseminating information on hepatitis B contributes to the debunking of myths and prejudices. 


\section{Resumo}

Avaliação da prevalência de transmissão vertical de hepatite $\mathrm{B}$ em duas gerações consecutivas

Introdução: A hepatite B é um importante problema de saúde pública no mundo e uma das formas de contágio seria através da transmissão vertical. O diagnóstico precoce possibilita a adoção de medidas de profilaxia, o que resulta na prevenção em mais de $90 \%$ dos casos.

Objetivo: Descrever as prevalências de transmissão vertical e comparar duas gerações (mãe/paciente e paciente/filho).

Método: Trata-se de um estudo transversal, que incluiu 101 pacientes. As entrevistas foram realizadas por meio da aplicação do instrumento de coleta de dados e informações do prontuário físico antes da consulta médica. Resultados: A média \pm DP de idade foi de 50,9 \pm 13,1 anos, houve predomínio do gênero masculino, com $56,4 \%$ dos pacientes, e predominou a cor branca, com $43,6 \%$. A transmissão vertical entre mãe do paciente/paciente ocorreu em $17,8 \%$ e entre paciente/filho, em 7,9\%. Em todos os oito casos de transmissão vertical, o diagnóstico foi posterior ao nascimento dos filhos infectados por HBV; em 3/8 (37,5\%), houve mais de um caso de infecção por esse mecanismo por paciente, totalizando 13 filhos com a doença.

Conclusão: Houve uma redução na transmissão vertical, mostrando que as medidas preventivas foram efetivas.

Palavras-chave: Hepatite B. Transmissão Vertical de Doença Infecciosa. Antivirais.

\section{References}

1. Abreu RM. Validação de um questionário para a avaliação da adesão ao tratamento antiviral em pacientes portadores de hepatite B crônica [dissertation]. São Paulo: Faculdade de Medicina, Universidade de São Paulo; 2013.

2. Ono-Nita SK, Carrilho FJ, Cardoso RA, Nita ME, Silva LC. Searching for chronic hepatitis $\mathrm{B}$ patients in a low prevalence area: role of racial origin. BMC Fam Pract. 2004; 5:7.

3. Brasil. Ministério da Saúde. Secretaria de Vigilância em Saúde. Departamento de Vigilância, Prevenção e Controle das DST, Aids e Hepatites Virais. Protocolo clínico e diretrizes terapêuticas para prevenção transmissão vertical de HIV, sífilis e hepatites virais. Brasília: Ministério da Saúde; 2015.

4. Terrault NA, Bzowej NH, Chang KM, Hwang JP, Jonas MM, Murad MH American Association for the Study of Liver Diseases. AASLD guidelines for treatment of chronic hepatitis B. Hepatology. 2016; 63(1):261-83.

5. Brasil. Ministério da Saúde. Secretaria de Vigilância em Saúde. Departamento de Vigilância, Prevenção e Controle das DST, Aids e Hepatites Virais. Protocolo clínico e diretrizes terapêuticas para hepatite B e coinfecções. Brasília: Ministério da Saúde; 2016

6. Cheung KW, Seto MTY, Wong SF. Towards complete eradication of hepatitis $B$ infection from perinatal transmission: review of the mechanisms of in utero infection and the use of antiviral treatment during pregnancy. Eur J Obstet Gynecol Reprod Biol. 2013; 169(1):17-23.

7. Kim HY, Choi JY, Park CH, Jang JW, Kim CW, Bae SH, et al. Outcome after discontinuing antiviral agents during pregnancy in women infected with hepatitis B virus. J Clin Virol. 2013; 56(4):299-305.

8. Dionne-Odom J, Tita AT, Silverman NS. Society for Maternal-Fetal Medicine (SMFM) Consult Series \#38: hepatitis B in pregnancy - screening, treatment, and prevention of vertical transmission. Am J Obstet Gynecol. 2016; 214(1):6-14.

9. Brasil. Ministério da Saúde. Secretaria de Vigilância em Saúde. Departamento de Vigilância, Prevenção e Controle das DST, Aids e Hepatites Virais. Boletim Epidemiológico - Hepatites Virais. Brasília: Ministério da Saúde; 2016.

10. Brasil. Ministério da Saúde. Secretaria de Vigilância em Saúde. Departamento de Vigilância Epidemiológica. A, B, C, D, E de hepatites para comunicadores / Ministério da Saúde, Secretaria de Vigilância em Saúde, Departamento de Vigilância Epidemiológica. Brasília: Ministério da Saúde; 2005.

11. Divisão de Imunização. Divisão de Hepatites. Centro de Vigilância Epidemiológica "Prof. Alexandre Vranjac". Coordenadoria de Controle de Doenças. Secretaria de Estado da Saúde de São Paulo - DI/DH/CVE/CCD/ SES-SP. Vacina contra hepatite B. Rev Saúde Pública. 2006; 40(6):1137-40.

12. Zhuang H. [Prevention of mother-to-child transmission of hepatitis B virus]. Zhonghua Gan Zang Bing Za Zhi. 2016; 24(23):881-4.

13. Brasil. Ministério da Saúde. Secretaria de Vigilância em Saúde. Departamento de Vigilância das Doenças Transmissíveis. Manual dos centros de referência para imunobiológicos especiais / Ministério da Saúde, Secretaria de Vigilância em Saúde, Departamento de Vigilância das Doenças Transmissíveis. 4. ed. Brasília: Ministério da Saúde; 2014

14. World Health Organization. Guidelines for the Prevention, Care and Treatment of Persons with Chronic Hepatites B Infection. Geneva: World Health Organization; 2015. 